\title{
INTERDISCIPLINARIDADE NA FORMAÇÃO DA SENSIBILIDADE HUMANÍSTICA DO JURISTA E A ESTEREOTIPAÇÃO DO POSITIVISMO E DO JUSNATURALISMO NA OBRA OS MISERÁVEIS
}

\author{
FRANCE FERRARI CAMARgo DOS SANTOS ${ }^{1}$ \\ ELIZÂNGELA TREMÉA
}

\begin{abstract}
RESUMO: Considerando os promissores resultados do Direito na Literatura, suas interfaces e conexões, este trabalho busca defender o diálogo interdisciplinar como prática pedagógica na formação da sensibilidade humanística do jurista, tendo como princípio norteador a hermenêutica jurídica e literária. Por meio do método dedutivo, utilizado em pesquisa qualitativa, esta pesquisa engloba a importância da interdisciplinaridade na formação da sensibilidade humanística do jurista, a contribuição da arte literária para o ensino do direito, bem como a análise de dois dos personagens centrais da obra Os miseráveis, de Vitor Hugo, correlacionando-os como estereótipos das concepções positivista e jusnaturalista em relação à lei e a algumas atitudes humanas. Questiona o papel da literatura no ensino jurídico e na constituição do sujeito que ocorre, impreterivelmente, da diversidade, historicidade e sociabilidade. Assumir a postura interdisciplinar do Direito com a Literatura possibilita o rompimento de barreiras que ainda permanecem rígidas, especialmente na tarefa de se repensar o direito e a formação do jurista para além do positivismo jurídico. Portanto, a correlação dessas duas disciplinas, principalmente por se considerar a função emotiva e formadora da Literatura, é uma proposta de estudo interdisciplinar em prol de uma formação jurídica também voltada à formação da sensibilidade humanística do jurista.
\end{abstract}

1 Especialista em Educação Especial. Professora de Língua Portuguesa e Literatura na Rede Estadual de Ensino do Estado do Paraná. Graduada em Direito pela Universidade Estadual do Oeste do Paraná (UNIOESTE). Marechal Cândido Rondon (PR), Brasil. CV Lattes: http://lattes.cnpq.br/67210737774002573. ORCID: https://orcid.org/oooo0003-2405-6896.E-mail: franceferrari@hotmail.com.

2 Graduada em Direito pela Universidade Regional do Noroeste do Estado do Rio Grande do Sul (UNIJUÍ). Mestre em Ciências Sociais Aplicadas pela Universidade Estadual de Ponta Grossa (UEPG). Doutora em Educação pela Pontifícia Universidade Católica de São Paulo (PUC-SP). Professora do Curso de Direito da Universidade Estadual do Oeste do Paraná (UNIOESTE). Líder do Grupo de Pesquisa Hermenêutica das Ciências $e$ Soberania Nacional (UNIOESTE). Membro do GEDAIS - Grupo de Estudos em Direito Ambiental, Internacional e Sustentabilidade (UNIOSTE). Coordenadora do Núcleo de Estudos e Defesa de Direitos da Infância e da Juventude (USF). Marechal Cândido Rondon (PR), Brasil. CV Lattes: http://lattes.cnpq.br/7360871415803887. ORCID: https://orcid.org/o000-0003-1522-8430. E-mail: elizangelatremea@hotmail.com. 
Palavras-Chave: interdisciplinaridade; formação; sensibilidade; positivismo; jusnaturalismo.

\section{INTRODUÇÃO}

A primeira relação que se estabelece é a de que, sem ressalvas, Direito e Literatura são possíveis somente se houver um meio sem o qual ambos não existiriam: a palavra. Tal palavra, como bem define Lenio Luiz Streck, é "pá que lavra”, é meio, é instrumento, é ação, é significante e significado, é som, é símbolo, é caminho e caminhada. Partindo desse pressuposto, e também porque não parece coerente outro ponto de partida para essa reflexão, Direito e Literatura estabelecem conexões tais que viabilizam um estudo aprofundado, tendo como foco principal a leitura, a interpretação e a construção de uma visão crítica e sensível da realidade social (literatura) e, consequentemente, do fenômeno jurídico (direito).

Assumir uma postura interdisciplinar do Direito com a Literatura possibilita o rompimento de barreiras que ainda permanecem rígidas, especialmente na tarefa de se repensar o direito e a formação do jurista para além do positivismo jurídico.

Nesse sentido, parafraseando André Karam Trindade (2008), tornase um grande desafio defender um estudo voltado às diversas formas de enlaces disciplinares, principalmente face aos mais variados discursos vinculados à ideia de que tais propostas de estudo são entretenimento ou que são uma espécie de fuga dos temas realmente sérios, principalmente no campo do Direito, sempre aparentemente robusto, simbolicamente onipotente e complexo como verdadeiramente o é, diante da obscuridade do seu ordenamento jurídico.

A interdisciplinaridade entre Direito e Literatura pode ser um caminho e, mais que isso, uma metodologia importante em defesa de uma formação jurídica humanística. Caminho este que se mostra bastante promissor, principalmente dada à inquestionável capacidade de transformação que a obra de arte em geral provoca nos leitores.

Nesse sentido, torna-se relevante que se estabeleça entre as ciências jurídica e literária uma viabilidade de estudo interdisciplinar em busca de uma formação acadêmica jurídica menos tecnicista, mais humana. Trata-se, 
primeiramente, de um despertar para a necessidade de leitura literária, fomentando a reflexão crítica a respeito do conhecimento jurídico e do papel do operador do direito na sociedade, bem como reflexão para além da racionalidade prática, mas a partir de uma racionalidade emocional, sensível e empática por meio da cultura, da arte e, especificamente, da Literatura.

São, portanto, urgentes as abordagens e reflexões sobre a necessidade de um ensino jurídico mais voltado à formação da sensibilidade humanística do jurista e a importante contribuição da Literatura em interface com o Direito como metodologia interdisciplinar.

Como amostra de estudo interdisciplinar, personagens da obra Os miseráveis, de Vitor Hugo, serão analisados à luz de duas concepções de destaque para o Direito: o jusnaturalismo e o positivismo jurídico. Dois personagens dessa obra se tornam estereótipos em representar com propriedade tais concepções: Monsenhor Bienvenu e o Inspetor Javert.

Dessa forma, por meio de um pequeno exemplo de interdisciplinaridade entre as disciplinas Direito e Literatura, evidencia-se a competência da Literatura em auxiliar o ensino do Direito para além do positivismo e racionalismo técnicos.

O método utilizado nesta pesquisa é o método bibliográfico dedutivo, direcionando-se à revisão bibliográfica da literatura jurídica e literária e na análise de sua inter-relação com uma das obras clássicas da literatura universal. Com efeito, a presente pesquisa tem a sua relevância decorrente da reflexão que se propõe sobre a interdisciplinaridade do Direito com a Literatura e sua contribuição para a formação de uma sensibilidade jurídica mais humanística.

\section{POR UMA FORMAÇÃO DA SENSIBILIDADE HUMANÍSTICA DO JURISTA}

A interdisciplinaridade do Direito com outras áreas do conhecimento, como sociologia, psicologia, antropologia, filosofia e demais manifestações artísticas, são de considerável importância para a formação humanística, crítica e sensível do jurista. A relevância e o papel que a Arte, de uma maneira geral, tem de influenciar na humanização do ser é inquestionável. José Roberto de Castro Neves afirma (2015), inclusive, que o raciocínio 
jurídico é analógico e, assim o sendo, precisa de um ponto de partida que, a seu ver, não pode ser outro senão o da cultura. Para esse autor,

[...] o direito, como se disse, reclama essa apreciação analógica. Os fatos da vida, que servem de fonte à análise legal, não vêm prontos, tal como uma pesquisa feita no computador. O intérprete deve encontrá-los por meio do referido raciocínio analógico, que reclama padrões e pontos de partida. Sem cultura, essa busca, se não impossível, é, ao menos, seriamente comprometida (2015, p. 31).

Se a cultura é o ponto de partida fundamental, então é por meio das mais variadas formas de sua manifestação pela Arte (literatura, teatro, música, dança, pintura, cinema e outras) que encontramos o caminho de interseção com o Direito.

Diante dessa variedade de possibilidades de encontro da Arte com o Direito, Richard Rorty situa "a literatura como ferramenta crítica fundamental quando se trata de refletir sobre os valores essenciais da humanidade” (apud Talavera, 2015, online), outorgando à literatura um valor até mesmo superior ao da própria filosofia.

Segundo Melina Girardi Fachin,

Tanto o direito quanto a arte possuem o mesmo caráter ontológico, qual seja, a manifestação expressiva através do homem. Dentro das manifestações artísticas, a literatura ganha destaque pois possui um modo peculiar de "tocar" as pessoas (apud Trindade et al., 2010, p. 382).

Esse modo peculiar de tocar as pessoas, próprio da Literatura, é o que a capacita como ferramenta metodológica eficaz na interdisciplinaridade com o Direito em prol da humanização do jurista.

Nesse mesmo sentido, ao supor um possível diálogo entre o discurso jurídico e o discurso literário, Fachin colabora com a ideia de que esse "fenômeno" traria para o Direito uma série de benefícios no que se refere a sua práxis, caracterizando mais do que uma forma de interpretação do discurso jurídico, mas "uma abrangência hermenêutica maior, em termos de compreensão" (apud Trindade et al., 2010, p. 380-381).

Importante salientar que esse fenômeno, conforme a própria autora afirma, está relacionado com o poder da Literatura e dessa interdisciplinaridade com o Direito ser algo mais do que apenas uma ferramenta interpretativa. A Literatura pode servir "para a construção de uma ponte entre a esfera teórica e a prática do discurso jurídico e, até 
mesmo, mais do que isso: como um instrumento pedagógico capaz de conscientizar a sociedade da existência factível de direitos fundamentais" (apud Trindade et al., 2010, p. 381).

No entanto, o estudo do Direito por meio dessas relações e a metodologia interdisciplinar é ainda bastante recente. Alguns sociólogos, filósofos, juristas, linguistas e críticos literários têm defendido esse estudo transdisciplinar, principalmente num contexto de ciência "pós-moderna", que sugere coexistência pacífica entre diferentes culturas, cujas expressões mais relevantes se manifestam por meio da linguagem e do direito.

Sendo assim, torna-se de grande valia considerar as funções da Literatura e do Direito, bem como os pontos principais de interseção entre um e outro, de forma a reforçar a necessidade de interdisciplinaridade entre ambos como metodologia de ensino, cujo objetivo é a formação da sensibilidade humanística do jurista.

\subsection{Literatura e formação humanística}

Importante estudioso do tema Direito e Literatura, Streck indaga constantemente sobre "quanta realidade se encontra nas ficções" e "quanta ficção conforma nossa realidade". Ele faz uma citação remetendo-a aos irmãos Grim, mais especificamente a Jacob Grim (1785-1863) que estudou direito em Masburgo, a notável comparação: “o direito e a poesia se levantaram de um mesmo leito" (2013, p. 3).

Para Juliana Azevedo Arneitz, a interdisciplinaridade entre Direito e Literatura requer prévia investigação a respeito da relação da literatura com o modo de produção da vida, devendo haver um pré-questionamento sobre "se a literatura é um espelho da vida, constituindo-se como uma fonte histórica perfeita, ou se possui uma natureza própria, o que a tornaria uma forma de representação bastante peculiar do mundo" (2017, online).

Se espelho da vida, se realidade na ficção, se, ainda, ficção na realidade, o que importa, como reitera Streck, é que "nas obras literárias, o caráter ficcional não só contrapõe como é o que possibilita a representação da realidade" (2013, p. 3). São temas centrados em análises da relação da literatura com o direito por meio da "realidade da ficção". Já no âmbito da "ficção da realidade", há enfoque maior nos aspectos políticos, jurídicos e sociais, "evidenciando que alguns dos elementos que conformam a 
realidade brasileira encontram, muitas vezes, extrema proximidade com os componentes diegéticos do universo ficcional” (2013, p. 4). Assim, o direito pode ser contado a partir da literatura, forma pela qual além de se possibilitar a humanização do direito, mostra que ele não "precisa desempenhar sempre o papel de vilão da história" (2013, p. 6).

A Literatura tem poder de ensinar ao Direito. E mais, afirma Streck que a literatura tem o poder de "humanizar" o direito e que, aliás, ela permite a ocorrência de

[...] vários modos de dizer as coisas. Uma ilha é um pedaço de terra cercado por água, mas também pode ser um pedaço de terra que resiste bravamente ao assédio dos mares. É comum dizer que o galo canta para saudar a manhã que chega; mas, quem sabe, ele canta melancolicamente a tristeza pela noite que se esvai (2013, p. 227).

Essa é uma das características peculiares da Literatura, capaz de transcender a linguagem e transformá-la em sentido metafórico, artístico, sensível e belo, efeito este que só a arte é capaz de promover.

E assim, interdisciplinarmente, o ensino do direito pode se valer da leitura e análise de diversas obras da literatura clássica - desde os gregos até os clássicos modernos e contemporâneos - de forma a inter-relacionar saberes, com o objetivo de ampliar o conhecimento e abrangência do saber jurídico.

É apenas uma contribuição, ou melhor, um caminho a mais a ser trilhado em prol da superação da crise no ensino jurídico. Contudo, apenas mais uma proposta que pode colaborar no sentido de um ensino mais voltado à humanização do Direito, valendo-se, essencialmente, da contribuição auferida aos poderes que a Arte é capaz de produzir, nesse caso em especial, a Arte Literária.

Antonio Candido, mestre da crítica literária brasileira, atribui à Literatura uma função educativa. Para ele, a literatura possibilita uma investigação sobre o ser "humano" em seus mais diversos aspectos e relacionamentos intersociais.

No entanto, Afrânio Coutinho defende a autonomia do ensino literário e confere à Literatura um caráter apenas fenomênico e estético. A Literatura para ele é a arte da palavra que proporciona prazer, ou seja, sua finalidade transcende a educação e o estudo social. As características 
educativas podem ser atribuídas à Literatura, mas apenas secundariamente. Afirma que Literatura não é documento e com ela "não se visa a aprender, nem informar, nem documentar. E nenhum leitor a procura para realizar qualquer dessas atividades" (Coutinho, 1978, p. 9).

Nesses termos, Afrânio Coutinho defende a Literatura como manifestação da arte e como forma de transfiguração do real, ou ainda como recriação da realidade. Nas suas palavras,

[...] a literatura é uma arte, a arte da palavra (nem tudo o que utiliza a palavra é literatura, sendo mister que o faça de maneira específica) e, como toda arte, origina-se na imaginação criadora, cujo objetivo é despertar um estado emocional, um prazer artístico. Não visa, portanto, ao conhecimento, à informação, ao ensinamento. Não é por aí que as obras literárias se tornam eternas na admiração e no prazer dos leitores. Mas sim pelos elementos estético-literários que constituem o intrínseco de sua composição, e que são responsáveis pelo seu valor especificamente literário e pelo prazer estético advindo de sua leitura (1978, p. 91).

\section{Além disso, afirma ainda que a literatura é}

[...] assim, vida, parte da vida, não se admitindo possa haver conflito entre uma e outra. Através das obras literárias, tomamos contacto com a vida, nas suas verdades eternas, comuns a todos os homens e lugares, porque são as verdades da mesma condição humana (Coutinho, 1978, p. 10).

Designar ao papel da Literatura um caminho de contato com a vida e suas verdades eternas é uma forma de atribuir a ela um importante papel na formação humanística do ser. Assim, Afrânio Coutinho reitera a função da Literatura e a assemelha ao conceito de verossimilhança, criado por Aristóteles em sua obra Poética. A verossimilhança presente na Poesia para Aristóteles equivale à função da Literatura em possibilitar o contato com as verdades humanas eternas. Segundo Aristóteles,

[...] a obra do poeta não consiste em contar o que aconteceu, mas sim coisas que podiam acontecer, possíveis no ponto de vista da verossimilhança ou da necessidade.

Não é em metrificar ou não que diferem o historiador e o poeta; a obra de Heródoto podia ser metrificada; não seria menos uma história com o metro do que sem ele; a diferença está em que um narra acontecimentos e o outro, fatos quais podiam acontecer. Por isso, a Poesia encerra mais filosofia e elevação do que a História; aquela enuncia verdades gerais; esta relata fatos particulares. Enunciar verdades gerais é dizer que espécie de coisas um indivíduo de natureza tal vem a 
dizer ou fazer verossímil ou necessariamente; a isso visa a Poesia, ainda quando nomeia personagens (1981, p. 28, grifos nossos).

Aristóteles evidencia o ofício da Poesia, dada a sua natureza de imitação - mímesis ou representação - e seu âmbito em relação à História. A Literatura não se atém a narrar os fatos simplesmente, como os faz a História, mas cumpre essencialmente o ofício de "enunciar verdades gerais" de forma verossímil, o mais semelhante possível à vida real.

$\mathrm{O}$ aspecto de verossimilhança com a realidade, segundo Antonio Candido, era, num primeiro momento, considerado de essencial importância numa obra de arte literária e que, posteriormente,

[...] chegou-se à posição oposta, procurando-se mostrar que a matéria de uma obra é secundária, e que a sua importância deriva das operações formais postas em jogo, conferindo-lhe uma peculiaridade que a torna de fato independente de quaisquer condicionamentos [...] (2000, p. 5).

Contudo, o mesmo crítico literário reitera que

[...] a integridade da obra não permite adotar nenhuma das visões dissociadas; e que só a podemos entender fundindo texto e contexto numa interpretação dialeticamente íntegra, em que tanto o velho ponto de vista que explicava pelos fatores externos, quanto o outro, norteado pela convicção de que a estrutura é virtualmente independente, se combinam como momentos necessários do processo interpretativo. Sabemos, ainda, que o externo (no caso, o social) importa, não como causa, nem como significado, mas como elemento que desempenha um certo papel na constituição da estrutura, tornando-se, portanto, interno (Candido, 2000, p. 5-6).

Assim, a obra de arte literária além de permitir a representatividade verossímil da realidade e pressupor certo grau de estética e estilística, requer, segundo Antonio Candido, respeito a sua integridade, valorizando a interpretação dialética entre texto e contexto, uma verdadeira fusão entre os aspectos internos e externos da obra.

Como se observa pelos ensinamentos da Poética de Aristóteles, além de ser um campo de deleite do saber, da cultura e do letramento, a arte literária tem sido considerada, desde os primórdios da história do conhecimento ocidental, como meio de "purificação", ou ainda, "purgação" dos sentimentos ou emoções mais ocultas. 
Alfredo Bosi, professor emérito de Literatura Brasileira da USP, concorda em atribuir à literatura uma função libertadora, porém afirma que tal função "não é a única: é uma delas e que tem seu lugar de estudo específico na relação obra/leitor" (apud Rocco, 1992, p. 99).

Muitos críticos literários conferem à Literatura a função catártica, libertadora; outros a função ideológica, política ou social; há ainda os que defendem a função utópica e até mesmo a futurística. São, portanto, muitas e diversas as funções atribuídas à Literatura por muitos autores ao longo do tempo: educativa, estética, histórica, catártica, ideológica, política, social, entre outras. No entanto, o que se depreende de mais significativo é que a Literatura é capaz de suscitar o "belo" e o "sensível" que, aliás, pode ser alcançado fazendo uso de todas ou apenas algumas das suas funções literárias. E assim, "quando o autor sabe o que deseja, pode combinar todas as funções ao mesmo tempo e extrair diversos tipos de leituras, renováveis para cada leitor" (Czekster, online).

Nas palavras de Antoine Compagnon:

[...] retenhamos disso tudo o seguinte: a literatura é uma inevitável petição de princípio. Literatura é literatura, aquilo que as autoridades (os professores, os editores) incluem na literatura. Seus limites, às vezes se alteram, lentamente, moderadamente, mas é impossível passar de sua extensão à sua compreensão, do cânone à essência. Não digamos, entretanto, que não progredimos, porque o prazer da caça, como lembrava Montaigne, não é a captura, e o modelo de leitor, como vimos, é o caçador (2010, p. 46).

Nesse sentido, além das funções designadas à Literatura, considera-se ainda o incrível papel atribuído ao leitor do texto literário que, "caçador", infere-se no sentido e função máxima da arte literária: prazer estético somado à inevitável e consequente formação humanística de si mesmo.

Para Fachin, por meio da literatura somos capazes de "nos colocarmos novamente no lugar dos que vivem ao nosso entorno, de apreender de forma contida seus sentimentos e aspirações. É a literatura um dos elementos capazes de trazer à tona a ideia de 'fraternidade' e 'alteridade' de forma clara” (apud Trindade et al., 2010, p. 397).

Eduardo Carlos Bianca Bittar ensina que a "rudeza, frieza e insensibilidade bloqueiam pontes de acesso a alter" (2012, p. 695). Entende-se, portanto, que o caminho que se deva percorrer para o devido 
entendimento das dores do "outro", ou do sentimento do que é descrito por alteridade, seja possível por meio da capacidade de sensibilidade humanística.

\section{DA LITERATURA AO DIREITO: UMA ANÁLISE INTERDISCIPLINAR}

A literatura, enquanto forma de arte, responde com hombridade ao oportunizar aos leitores adentrar profundamente em grandes questões da natureza humana. A importância de ler e analisar um clássico da literatura universal, por conseguinte, é poder tomar contato com questionamentos sociais e naturalmente humanos, e encontrar, muitas vezes e das mais variadas formas, acalento para os diversos conflitos existenciais.

A obra Os miseráveis (Les Misérables) é uma das principais produções artísticas do escritor francês Victor Hugo, publicada em 3 de abril de 1862. Esse romance foi considerado um dos maiores acontecimentos literários da época, continuando vivo e atualíssimo, encantando leitores de todas as idades e lugares do mundo. Depois de Shakespeare, Victor Hugo foi "o autor ocidental que gerou mais estudos literários, análises filosóficas, edições críticas, biografias, traduções e adaptações de suas obras nos cinco continentes" (Vargas Llosa, 2012, p. 13).

Nesse sentido, torna-se quase impossível ao leitor dessa obra, por mais desatento que seja, não ser atingido por questões existenciais e instigado a refletir sobre aspectos cruciais da condição humana.

Caracterizado como romance social, Os miseráveis é um reflexo dos costumes da França do século XIX, revelando complexa trama e desenvoltura espetacular de seus diversos e significativos personagens.

Com características românticas, mas também realistas, a obra é considerada de grande importância social, pois representa crítica e denúncia a vários tipos de injustiça humana.

A história dessa obra se desenvolve entre dois momentos históricos da França: desde a Batalha de Waterloo, em 1815, a qual representou a queda do sonho imperialista de Napoleão Bonaparte, até os motins em Paris no mês de junho de 1832, quando estudantes republicanos tentaram, em vão, derrubar o regime do rei Luís Filipe I. 
Nesse contexto, narra a emocionante história de Jean Valjean, um homem que praticou o delito de "furto famélico"3 ao quebrar a vitrine de uma padaria para pegar um pão, sendo por isso julgado e condenado a cumprir pena de prisão resultando, decorrente das várias tentativas de fuga, em dezenove anos de cumprimento de pena.

O que se verifica, em primeiro plano nessa obra, é a questão primordial de empasse entre o direito positivo e o direito natural. Um exemplo de obra prima que traduz em situações fictícias o que a realidade suporta, revelando, por meio de exemplos, linguagem, técnica narrativa, personagens e tramas sociais, que, na verdade, nem sempre o direito resulta em justiça. Seria possível, mediante a riqueza dos elementos composicionais da obra, realizar inúmeras análises e levantar também inúmeros aspectos relevantes a uma interdisciplinaridade do direito com a literatura.

No entanto, este estudo é direcionado à análise interdisciplinar de dois personagens principais, cujas ações e atitudes representam estereótipos aos quais podemos associar as concepções positivistas e jusnaturalistas frente ao direito e a justiça.

\subsection{Enredo e personagens: Jean Valjean, Monsenhor Bienvenu e Javert}

Os miseráveis foi escrito e subdividido em cinco partes, cada qual sendo nomeado e dedicado de forma especial a um determinado personagem (Fantine; Cosette; Marius; O idílio da Rua Plumet e a epopeia da Rua Saint-Denis; Jean Valjean) e sua condição de vida no contexto social da França do início do Século XIX. É uma obra de ficção, mas que compete descrever o que no fundo os homens daquela época queriam ou pensavam ser,

[...] isto é, seres animados por maneiras de agir que o romantismo concebia de maneira esquemática, como emblemas de vícios ou virtudes incompatíveis entre si, capazes de se encarnar em indivíduos sem nuances que os manifestam ininterruptamente em todas as suas ações.

\footnotetext{
Na sociedade atual, em pleno Estado Democrático de Direito, esse delito não é mais considerado crime, muito menos poderá o praticante ser condenado já que agiu em estado de necessidade. No entanto, há não muito tempo, uma empregada doméstica passou por uma situação análoga a do personagem por furtar roupas e sapatos em uma loja de São Paulo. Notícia publicada na Folha de São Paulo, em 09 ago. 2010. Disponível em: <http://www1.folha.uol.com.br/fsp/cotidian/ffogo8201006.htm> Acesso em: 14 abr. 2017.
} 
Cada época tem a sua irrealidade: seus mitos, seus fantasmas, suas quimeras, seus sonhos e uma visão ideal do ser humano que a ficção expressa com mais fidelidade que qualquer outro gênero (Vargas Llosa, 2012, p. 63).

O personagem central da história é Jean Valjean, cuja sina é sofrer as injustas penas impostas pelo Estado quando da prática de um crime de furto qualificado. Esse personagem fora criado pela irmã que mais tarde ficara viúva, tendo sete filhos para criar. Muito trabalhador, logo se tornou arrimo da família. Não tardou, portanto, que ficasse sem emprego e em situação de extrema necessidade. Tal situação o levou a quebrar a vitrine de uma panificadora e furtar um pão para saciar a fome de sua família. Pego em flagrante, foi condenado a cinco anos de prisão.

Jean Valjean foi declarado culpado. As palavras do código eram formais. Há momentos terríveis em nossa civilização: quando a penalidade anuncia o naufrágio. Que minuto funesto aquele em que a sociedade se desvia e decreta o irreparável desamparo a uma criatura racional! Jean Valjean foi condenado a cinco anos de galés (Hugo, 2014, p. 124).

Depois de reincidentes tentativas de fuga e novas condenações, Jean Valjean acabou cumprindo dezenove anos de prisão, tendo sido obrigado, durante todo esse tempo, a prestar serviços forçados nas galés ${ }^{4}$ francesas. Ao receber o benefício da liberdade condicional, teve de levar consigo um "passaporte amarelo" que o estigmatizara como "ex-condenado" e de "alto risco" para a sociedade.

Marginalizado em razão da sua história e discriminado pela identificação que carregava, não conseguiu nem trabalho nem um local para se abrigar. Porém, encontrou na bondade do Bispo Monsenhor Bienvenu, uma chance de redenção. O Bispo ofereceu-lhe comida, pouso e confiança. Mas, Jean Valjean, tão fortemente apegado ao monstro no qual havia se transformado ao longo de tanto tempo encarcerado, acabou furtando os talheres de prata do Bispo e fugindo durante a noite.

No outro dia, soldados trouxeram o fugitivo juntamente com a prataria até o Bispo para checarem o ocorrido. Nesse momento, prevendo o que havia acontecido, Monsenhor Bienvenu se antecipa e diz aos soldados

A pena das galés era uma punição na qual os condenados cumpriam a pena com trabalhos forçados. Era uma espécie de sanção criminal que determinava aos réus trabalharem acorrentados às embarcações movidas a remo, que só adentravam ao mar mediante a força de muitos homens. 
que a prataria havia sido presenteada ao hóspede que, ao despedir-se, havia esquecido de levar consigo também os castiçais que eram igualmente de prata. Com essa atitude, o Bispo não só o livrara da prisão como também lhe proporcionara uma tremenda reflexão sobre si mesmo, seu passado e seu futuro.

O narrador estabelece um papel importante ao levar o leitor a percorrer os mesmos caminhos que o personagem. Leva o leitor a perceber toda a introspecção pela qual passou Jean Valjean. Dentre muitas passagens, cita-se uma para exemplificar o choque que a atitude do Bispo de Digne5 causou no personagem:

\begin{abstract}
[...] fosse como fosse, esta última má ação produziu nele um efeito decisivo; atravessou rapidamente o caos que tinha no espírito e dissipou-o; colocou de um lado as trevas e de outro a luz, e agiu sobre sua alma, no estado em que estava, como certos reagentes químicos agem sobre uma mistura turva, precipitando um elemento e clarificando outro. [...]. Quando gritou: sou um miserável! Acabou enxergando-se tal como era, e já estava a tal ponto separado de si próprio, que ele aparentava a si mesmo não ser mais que um fantasma [...] (Hugo, 2014, p. 151-152).
\end{abstract}

A partir desse momento, mediante um ato de extrema consciência, Jean Valjean rasga seu passaporte amarelo e vai para bem longe. Na cidade de Montreuil-sur-Mer, adota o nome de Madeleine, tornando-se um homem próspero, dono de uma fábrica que abrigava "duas vastas oficinas, uma para homens, outra para mulheres" (Hugo, 2014, p. 203). Emprego, respeito e dignidade eram oferecidos a qualquer um que necessitasse. Madeleine era um homem íntegro, cuja fama se espalhava pelo povoado, não tardando a ser nomeado o prefeito daquele vilarejo.

Em meio a todos esses acontecimentos, havia ainda a figura do inspetor de polícia Javert, que conheceu Jean Valjean na prisão quando ainda era guarda-ajudante dos presos. Javert foi promovido a inspetor de polícia em Montreuil-sur-Mer. Era um homem frio, calculista, metódico, fiel cumpridor da lei. Aprendeu desde a infância a ver e agir sobre o mundo cruel das prisões, não tardando a se ingressar na polícia e a adotar uma postura rígida e amplamente temida pelos presos. Sua missão era fiscalizar, manter e impor a ordem e o severo cumprimento da lei. Jean Valjean o

\footnotetext{
Pequeno vilarejo francês.
} 
tinha como um fantasma, sempre em seu rastro. Para ele, o inspetor Javert era um monstro, "medonho cão de caça" (Hugo, 2014, p. 267) na busca incansável pelo criminoso fugitivo.

Depois do episódio da prisão do Senhor Champmathieu - confundido com o fugitivo Jean Valjean - o inspetor Javert comparece à prefeitura de Montreuil-sur-Mer para pedir desculpas ao prefeito (Sr. Madeleine) pela denúncia e suspeita que nutria profundamente a seu respeito, já que haviam prendido o tão procurado fugitivo. Nessa circunstância, Madeleine se apressa e comparece ao julgamento do preso Champmathieu, entregando-se como o verdadeiro fugitivo Jean Valjean. Por conta dessa confissão, um mandado de prisão fora expedido e entregue a cargo do inspetor Javert que, diante te tal façanha, culmina em êxtase por ter cumprido sua tão honrosa função. Assim descreve o narrador:

[...] naquele momento, Javert estava no céu. Sem claramente dar-se conta, no entanto, com uma intuição confusa de sua necessidade e de seu sucesso, ele personificava, ele, Javert, a justiça, a luz e a verdade, que tem função celeste acabar com o mal. Por trás e em volta dele, a uma profundidade infinita, tinha a autoridade, a razão, a coisa julgada, a consciência legal, a punição pública, todas as estrelas; ele protegia a ordem, fazia o raio sair da lei, vingava a sociedade, dava pulso forte ao absoluto, dirigia-se à glória; havia em sua vitória uma réstia de desafio e de combate; de pé, altivo, fulgurante, ele ostentava, no imenso azul, a bestialidade sobre-humana de um arcanjo feroz; a sombra temível da ação que conduzia tornava visível, em seu punho contraído, o vago flamejar da espada social; feliz e indignado, mantinha sob seus pés o crime, o vício, a rebelião, a perdição, o inferno; ele brilhava, ele exterminava, ele sorria, e havia uma incontestável grandeza naquele São Miguel monstruoso (Hugo, 2014, p. 333 , grifos nossos).

O personagem Javert é a personificação da imposição da ordem representada pela Lei e o Estado. Sua personalidade está moldada, revestida em atenção redobrada ao cumprimento severo das normas positivadas em garantia da ordem e da proteção social. Há tanto rigor em suas atitudes que ao se deparar com sua impotência em ser garantidor do cumprimento da lei e mantenedor da ordem na sociedade, Javert vive uma situação angustiante:

[...] via diante de si dois caminhos, ambos retos, mas via dois; e isso o apavorava, a ele, que nunca em sua vida conhecera senão uma única linha reta. E, angústia pungente, esses dois caminhos eram opostos. Qualquer 
uma dessas linhas retas excluía a outra. Qual delas era a verdadeira? (Hugo, 2014, p. 1368).

Diante do impasse ao qual se depara Javert pela primeira vez em sua vida, quando o caminho da lei é oposto ao da consciência; quando o que a lei determina entra em choque com a efetividade da justiça; quando não há possibilidade de ação em consonância com a punição do malfeitor, principalmente porque não mais o enxerga como aquela figura construída durante toda uma vida de perseguição; quando não se vê mais possível dentro de si mesmo, atira-se no rio Sena. Age rigorosamente contra si mesmo!

São esses, portanto, personagens de destaque, cada qual representando um papel de relevância a esta análise interdisciplinar do direito com a literatura na obra Os miseráveis de Victor Hugo.

\subsection{O estereótipo em Os miseráveis}

À luz do direito, a obra Os miseráveis apresenta inúmeras possibilidades de análises e interseções. No entanto, para o presente estudo, serão focalizados somente aspectos em relação a dois personagens, como dito anteriormente, Bispo Bienvenu e o inspetor Javert.

Tais personagens, fatos e direito a eles atribuídos revelam, ainda que de forma estereotipada, muito das características de um sistema jurídico pautado no positivismo, cujas normas de cunho eminentemente abstrato e geral, tinham como função garantir a segurança e o bem-estar social. Nesse sentido, explica Cesar Carneiro, que o contexto histórico da obra revela a realidade de um posicionamento jurídico no qual

[...] os códigos legais eram mecanismos utilizados pelo Estado para gerenciar o máximo possível da vida social. De observância obrigatória na sociedade, conteriam, pretensamente, todas as situações fáticas possíveis de serem observadas no meio social. Esse corpo de leis codificadas era legitimado por uma estrutura estatal burocrática que dava validade a esses diplomas legais. É a partir das codificações que se desenvolve a Cultura Jurídica Positivista, que ganha força devido ao caráter abstrato e geral das leis que garantiam maior segurança jurídica, se contrapondo e superando o Naturalismo Jurídico, imutável, preexistente em relação às leis e com grande carga axiológica. A Ideologia Positivista ganha força e passa a ideia de obrigatoriedade na observância do regramento positivado, de modo que somente através da lei é que se encontraria o Direito na sociedade, o Direito seria apenas aquilo que está disposto na lei válida, 
ou seja, lei elaborada institucionalmente pelo Estado de Direito (2016, online).

Assim, o Direito seria garantido pela lei que, em razão de sua imposição e cumprimento, seria por sua vez reflexo da Justiça. No entanto, "é no celeiro da injustiça penal que a obra ganha seu destaque contundente - a punição da bagatela, a pena desproporcional, a crueldade da prisão, a eternização da sentença, e a seletividade penal em todas as suas dimensões" (Semer, 2013, online).

Em razão dessa injustiça mascarada de ordem social e segurança jurídica que o escritor Victor Hugo denuncia por meio da brilhante obra literária Os miseráveis as terríveis mazelas e injustiças sociais do seu tempo. A marca inconfundível de sua presença onisciente na obra, revelando seu posicionamento e sua crítica feroz em meio aos acontecimentos, concretiza-se na forma da narrativa. É o narrador, segundo Vargas Llosa, o personagem principal de Os miseráveis, tornando-se personagem principal, portanto, o próprio escritor Victor Hugo, aquele que dá vida a esse narrador

[...] linguarudo que surge continuamente entre as suas criaturas e o leitor. Presença constante, arrebatadora, a cada passo ele interrompe o relato para opinar, às vezes em primeira pessoa e sob um nome que quer nos fazer acreditar que é o próprio Victor Hugo, sempre em voz alta e cadenciada, para interpolar reflexões morais, associações históricas, poemas, lembranças íntimas, para criticar a sociedade e os homens em suas grandes intenções ou suas pequenas misérias, para condenar seus personagens ou elogiá-los. Volta e meia ele nos afirma que é só um escriba de uma história anterior ao romance, real como a vida e verdadeira como a própria verdade, que precede, anula e transcende a ele, simples intermediário, mero copista do real (Llosa, 2012, p. 23).

Então, como narrador observador, cuja voz representa a própria pessoa de Victor Hugo ao "incorporar" o lugar de personagem principal da história, insta observar ainda que, dessa forma, além de dar vida a sua voz e por meio dela denunciar as misérias sociais de seu tempo, esse narrador permite ao leitor, constantemente, a reflexão sobre diversos aspectos importantes ao direito.

Na voz do narrador, o livro que o leitor tem

[...] diante dos olhos é, do princípio ao fim, em seu conjunto e em seus detalhes, sejam quais forem as intermitências, as exceções ou falhas, a caminhada do 
mal para o bem, do injusto para o justo, do falso para o verdadeiro, da noite para o dia, do apetite para a consciência, da podridão para a vida, da bestialidade para o dever, do inferno para o céu, [...] (Hugo, 2014, p. 12911292).

Segundo o professor da Faculdade de Direito da PUC-RS, Fábio Roberto D’Ávila, sob a perspectiva do direito penal, Os miseráveis é um livro maravilhoso "porque trabalha com muita propriedade dois temas que são centrais: o que é o crime, e como pensar esse fato criminoso - com o seu contexto ou sem o seu contexto; e o que é pena, o que se espera da pena e como ter esse criminoso de volta à sociedade" (Programa Direito \& Literatura, 2012, online). E ainda, sob a mesma perspectiva, a ideia central retratada de forma majestosa na obra é a ideia hoje já bastante difundida de que "nenhum crime pode ser pensado fora de seu contexto".

Por isso, a análise interdisciplinar das relações inexoráveis entre Direito e Literatura, que ora se apresenta, atém-se ao contexto históricosocial-jurídico da França do início do Século XIX. E, assim, limita a análise dos fatos ao seu tempo e ao seu contexto, o que, no entanto, não impede a possível e inevitável analogia que por acaso possa resultar das reflexões sobre o que ainda hoje é resquício daquele tempo, ainda que remoto e encoberto por outros mantos e conceitos, porém enraizado nas posturas, nos costumes e no próprio Direito da sociedade contemporânea.

Não é à toa que uma das funções da Literatura é justamente a de revelar atemporalidade da obra. Em qualquer momento, em qualquer contexto, a obra se regenera, amolda-se e contempla o novo tempo. O que é documentário certamente envelhece, mas o que é poesia, crítica, humano ou desumano, permanece novo. Com maestria, Victor Hugo escreve o seguinte prefácio para sua obra:

Enquanto, por efeito de leis e costumes, houver proscrição social, forçando a existência, em plena civilização, de verdadeiros infernos, e desvirtuando, por humana fatalidade, um destino por natureza divino; enquanto os três problemas do século - a degradação do homem pelo proletariado, a prostituição da mulher pela fome, e a atrofia da criança pela ignorância - não forem resolvidos; enquanto houver lugares onde seja possível a asfixia social; em outras palavras, e de um ponto de vista mais amplo ainda, enquanto sobre a terra houver ignorância e miséria, livros como este não serão inúteis (2014, p. 37). 
Não serão jamais inúteis! Neste caso, em especial, a utilidade que se impõe interpela o Direito e a Literatura "com o objetivo de descobrir as interfaces entre as disciplinas e transcender o foco tradicional dos estudos em Direito" (Silva, 2010, p. 9).

Assim, Ada Bogliolo Piancastelli de Siqueira afirma que "o direito consiste, primeiramente, na tentativa humana de buscar uma compreensão social" (2011, p. 142) e que a literatura "traça perspectivas ousadas ao direito antes mesmo que elas sejam consideradas viáveis no âmbito jurídico" (2011, p. 145). Dada essa capacidade de antecipação "ousada" do horizonte de expectativas do direito pela literatura e, ainda, ser da natureza do direito a busca constante pelo entendimento das relações sociais, far-seá, a seguir, a análise individual dos referidos personagens centrais da obra Os miseráveis à luz do Direito.

\subsection{Inspetor Javert: personificação do positivismo jurídico}

A questão social é extremamente exposta no enredo de Os miseráveis, mas de toda a trama se sobressai de suas entrelinhas o conflito existencial entre a norma e o princípio, o direito e a justiça, o certo e o errado, o justo e o injusto.

Tais conflitos são vivenciados principalmente pelo personagem do Inspetor Javert, cuja função é encontrar o fugitivo Jean Valjean, perseguindo-o incansavelmente durante todo o enredo da obra.

A visão legalista do inspetor Javert, homem fiel cumpridor e obcecado pela lei, associa-se ao princípio básico do "positivismo jurídico: rule of Law as a Law of rule ${ }^{6}$. Uma vez regra, posta, deve ser inexoravelmente obedecida, devendo os juízes aterem-se a seus limites expressos, vinculados por sua vez ao ordenamento jurídico em que a norma está incluída" (Söhngen, 2015, p. 110). Não se induz com essa crítica à visão positivista do personagem Javert a desnecessidade de cumprimento da norma, muito pelo contrário, o que se procura destacar são os exageros formais, legalistas, e os efeitos que tais condutas causam em relação à efetividade da justiça.

Tradução literal: "Regra da Lei como uma Lei da regra”, ou, "Estado de Direito como uma lei da regra”. 
A filosofia de vida e de justiça do policial Javert, segundo Vargas Llosa, está

[...] baseada em dois sentimentos simples - respeito à autoridade e ódio a toda forma de rebeldia -, está admiravelmente resumida na frase que ele diz a Monsieur Madelaine: "Meu Deus, que fácil é ser bom, difícil é ser justo" (I, VI, II, p. 220). O narrador, um romântico, detesta a lei: prefere os impulsos, o gesto individual e soberano à norma coletiva. Javert, como o juiz de Camus em $O$ estrangeiro, antepõe a justiça à vida, e o narrador, a vida à justiça. Ambos, sem saber, concordam que as duas coisas são incompatíveis [...] (2012, p. 80, grifos nossos).

O inspetor Javert tem como prerrogativa o condicionamento da ordem ao cumprimento da lei; a sua função ao exercício de constatação e obrigação do cumprimento fidedigno das normas; à sociedade a garantia da ordem, da segurança jurídica, da paz social. Assim se comporta esse personagem que, durante toda uma vida vigia, fiscaliza, obriga e faz cumprimento de todas as normas estatais. Javert incorpora um

[...] formalista. A lei deve ser aplicada e cumprida sem exceções, sem uma interpretação benévola ou qualquer discricionariedade. No caso, até mesmo porque transgredir a lei humana seria também uma transgressão da lei divina, como Hugo vai deixando transparecer no raciocínio do inspetor. Na atuação de Javert, fica evidente como a forma perde qualquer elo com a justiça, que deveria ser inerente ao direito [...] (Söhngen, 2015, p. 111).

Sistemático, metódico, formalista, Javert raciocina de acordo com os parâmetros do cientificismo positivista, abstendo-se de formular determinados juízos de valor, pois para Javert basta a existência e o respeito à norma para a concretização do direito. A ideia de justiça está atrelada ao dever-cumprir a lei. Sua afirmação de que "é muito fácil ser bom, o difícil é ser justo" (Hugo, 2014, p. 253) é um exemplo da concepção por ele adotada, pois para ser justo ele deveria apenas cumprir a lei, sem nenhum questionamento ou qualquer relação de juízo valorativo com o fato.

Segundo o positivismo jurídico, "a afirmação da validade de uma norma jurídica não implica também na afirmação do seu valor" (Bobbio, 1995, p. 131). Como se constata dos ensinamentos de Norberto Bobbio, das características fundamentais do positivismo jurídico, o primeiro problema 
que surge está justamente relacionado "ao modo de abordar, de encarar o direito" que para o positivismo é visto como um fato e não um valor.

Além disso, Bobbio destaca outra característica do positivismo jurídico que também nos remete ao comportamento do Inspetor Javert. Tal característica se revela por considerar "a norma como um comando, formulando a teoria imperativista do direito, que se subdivide em numerosas "subteorias", segundo as quais é concebido este imperativo: como positivo ou negativo, como autônomo ou heterônimo, como técnico ou ético" (1995, p. 132). Além de ser comando normativo, imperativo, a norma está inserida num ordenamento jurídico completo que abarca todas as situações, não havendo, portanto, lacunas nem normas contraditórias no direito, do qual resultaria a justiça se entendido sob a teoria da obediência absoluta, pois "lei é lei"7.

Se "lei é lei”, no positivismo jurídico caberia o questionamento sobre o que é o direito? E justiça?

Afirma Roberto Lyra Filho que,

[...] embora as leis apresentem contradições, que não nos permitem rejeitá-las sem exame, como pura expressão dos interesses daquela classe (dominante), também não se pode afirmar, ingênua ou manhosamente, que toda legislação seja Direito autêntico, legítimo e indiscutível. Nesta última afirmativa, nós nos deixaríamos embrulhar nos "pacotes" legislativos, ditados pela simples conveniência do poder em exercício. A legislação abrange, sempre, em maior ou menor grau, Direito e Antidireito: isto é, Direito propriamente dito, reto e correto, e negação do Direito, entortado pelos interesses classísticos e caprichos continuístas do poder estabelecido (1999, p. 8).

Em certo momento da trama, Javert se depara com situações que o levam a inevitáveis questionamentos sobre a sua conduta. Dúvidas assolam o pensamento do Inspetor Javert e o mundo não lhe aparenta mais lógico e simples, revelando-lhe uma complexidade esmagadora e insuportável. Um fato coloca Jean Valjean novamente cara a cara com Javert, mas dessa vez em situações opostas, tendo Jean Valjean a chance de acabar de vez com o perseguidor Javert.

Quando, em meio ao motim de 1832, ao declarar-se partidário da causa e se instaurar como espião no meio dos revolucionários, Javert foi

Aforismo do positivismo jurídico: “Gesetz ist Gesetz”. 
desmascarado e mantido preso pelos insurgentes, dentre os quais estava também Jean Valjean. Este, por sua vez, teve a oportunidade de matar o inspetor, já que inimigo na insurreição. No entanto, o liberta. Além disso, Jean Valjean revela a Javert seu novo endereço, caso quisesse prendê-lo depois de findando o motim. Acontece que o inspetor, em momento oportuno, diante do poder de prender novamente Jean Valjean e acabar de vez com a busca que havia se instalado há tantos anos, assim não consegue proceder, deixando Valjean para trás, sem prendê-lo. Nesse momento, o que descobre Javert?

[...] que a lei e a moral podem ser diferentes, até mesmo inimigas, e que ao libertar o galeote fugitivo agiu de acordo com seus sentimentos e contra a sua razão, que preferiu essa confusa, não escrita, regra moral surgida no interior da sua consciência individual, que o induzia a devolver um favor ao homem que lhe salvara a vida na barricada, à regra escrita, à lei social, que lhe ordenava devolver o presidiário foragido à prisão. [...]. Na realidade, descobriu a existência de verdades contraditórias, de valores incompatíveis entre si, a inexorável confusão entre o bem e o mal em certas experiências humanas. Perceber que o bem e o mal não são, como ele dava por certo, algo rigidamente separado e reconhecível, mas caminhos que se cruzam e descruzam e às vezes se perdem um no outro sem que seja possível distingui-los, aflige Javert e provoca nele a "conversão" que o leva a matar-se. O mais terrível que lhe acontece é descobrir que no seu próprio ser há algo que não controla, um sentimento que nubla a razão (Vargas Llosa, 2012, p. 82-83).

Descobrir-se impotente e confuso de tal modo a agir contrariamente aos seus preceitos, e ao que acreditava ser a sua função, provoca em Javert um enorme conflito existencial. Assim, confirma o narrador da história, Javert

[...] dizia a si mesmo que então era verdade, que havia exceções, que a autoridade podia ser confundida, que a regra podia ser insuficiente perante um fato, que nem tudo se enquadrava ao texto do código, que era preciso obedecer ao imprevisto, que a virtude de um criminoso podia preparar uma armadilha à virtude de um funcionário, que o monstruoso podia ser divino, que o destino tinha dessas ciladas, e pensava com desespero que ele mesmo não estivera ao abrigo de uma surpresa.

Era forçado a reconhecer que a bondade existia. Esse criminoso fora bom. E ele mesmo, coisa incrível, acabara de ser bondoso. Portanto, depravava-se.

Achava-se covarde. Tinha horror de si mesmo. 
Para Javert, o ideal não era ser humano, ser grande, ser sublime, era ser irrepreensível.

Mas acabara de falar [...] (Hugo, 2014, p. 1371).

Tal conflito leva Javert ao suicídio, jogando-se no Rio Sena. O extremismo - reflexo da angústia do personagem - é típico do exagero estilístico romântico, cujo obtivo se configura em exaltar virtudes ou vícios, estabelecer divergências e contrários extremos, estereotipar comportamentos. Nesse caso,

[...] a atuação de Javert suscita boa reflexão com relação a um legalismo desencarnado, que gera a distorção da legalidade e que se encontra em inúmeras decisões judiciais, em que juízes não acabam por abarcar a totalidade do papel que desempenham na configuração do direito, encurralados em um formalismo intelectual rígido e inescrupuloso (Söhngen, 2015, p. 112).

Contudo, o mais importante em relação à análise do personagem Javert é a reflexão que se pode construir em torno da sua personalidade e atuação perante à lei e à sociedade. Ao instituir-se como mantenedor da ordem e garantidor da segurança, em obediência cega aos imperativos da lei, Javert corporifica o positivismo jurídico. Sim, considera-se exagero, estereótipo, como já desatacado anteriormente, porém, instigante a uma análise interdisciplinar, na qual as interfaces da Literatura se cruzam com o Direito, resultando em conhecimento e apreensão do que foi o movimento do positivismo jurídico que dominou a cultura jurídica por mais de um século, restando nítidos resquícios desse movimento na sociedade contemporânea.

\subsection{Monsenhor Bienvenu: estereótipo de humanidade!}

O personagem do Bispo de Digne, Monsenhor Bienvenu, destaca-se por sua benevolência ao acolher um ex-condenado, cujo passaporte amarelo o configurava detentor de alta periculosidade perante a sociedade. Assim, por meio da bondade, caridade e humanidade, confere a Jeann Valjean algo muito além da justiça que lhe fora negada, pois

[...] o acolhimento do bispo, a quem rouba, e sua caridade, muito além da justiça, levam-no (Jean Valjean) ao recomeço decisivo: libertando-se do passado e do que o mundo considerava, recomeça uma nova vida inspirada no bem que lhe foi feito. Livre de si mesmo, é capaz de estar sempre pendente dos demais (Söhngen, 2015, p. 114). 
Para Monsenhor Bienvenu prevalece o princípio da dignidade da pessoa humana e os princípios do direito natural. Importa-lhe muito mais acreditar no ser humano e na sua capacidade inata de restituição da humanidade, do que considerar o tempo ou o motivo da sua prisão. A atitude do bispo contrariava a cultura jurídica dominante no contexto do positivismo jurídico da França do início do Século XIX, o qual não admitia muito menos previa uma possibilidade de ressocialização a um ex-detento. Naquela época,

[...] o Direito vigente exigia o cumprimento da lei a qualquer custo - caráter evidenciado pelas atitudes do personagem Javert. O sistema pregava a perseguição dos miseráveis por pequenos crimes, infrações que a sociedade não via como leves e que, portanto, justificavam penas rigorosas. Mecanismos de balanceamento de direitos não existiam, por isso, a gritante desproporcionalidade entre o delito cometido e a pena aplicada. Princípios atuais da insignificância, da proporcionalidade e da responsabilidade social eram constantemente violados (Costa, 2015, online).

Contrapondo-se a todo um sistema jurídico rigoroso e formalista, Monsenhor Bienvenu proporciona ao personagem Jean Valjean uma esperança de redenção, um caminho de liberdade e salvação perante um regime severo e uma pena injusta. Como bem se denota, não fosse o Bispo de Digne, Jean Valjean não teria coragem de se insurgir contra o sistema que o dominava e punia. Muito menos teria entrado em choque com sua consciência a fim de resultar em mudança de si mesmo e, mais do que isso, estaria a sofrer a pena mais cruel, cuja consequência se tornaria pior do que o próprio encarceramento: o julgamento social.

Porém, ao oportunizar uma chance de mudança e revolucionar a vida do ex-prisioneiro, Monsenhor Bienvenu cumpre um papel interessante na obra Os miseráveis. Embora seja citado somente no início da história, os reflexos de sua atitude acompanham Jean Valjean por todo o enredo, sobressaindo-se como personagem primordial a todo o restante da trama, pois sua atitude revela o necessário senso de humanidade que carece em uma sociedade pautada na cultura jurídica predominantemente positivista.

Embora o sistema jurídico penal da atualidade tenha sofrido inúmeras mudanças desde o contexto histórico abarcado pela obra, a prática de julgar, condenar e punir ainda resulta em muitas falhas e 
[...] análogo ao que ocorre com Valjean, o corpo social da atualidade, em sua maioria, também demonstra rejeição àqueles que já cumpriram penas. Sendo assim, muitas vezes, desprovidos de qualificação e privados de oportunidades, os ex-condenados voltam a cometer crimes. Em "Os miseráveis", a boa ação do bispo provoca em Jean um processo de "reumanização", deixando clara a ideia de que o homem pode mostrar-se bom e virtuoso, quando a sociedade deixa de lhe vedar oportunidades (Costa, 2015, online).

Esse processo de "reumanização" que ocorre com Jean Valjean devido à atitude de compaixão do Bispo de Digne, é um acontecimento raro e ainda hoje se institui como desafio em se tratando do egresso contemporâneo. Como pontua o jurista Marcelo Semer, "servindo como forma de perpetuar o estigma, o cumprimento da pena por si tem sido intrinsecamente o maior contribuinte para a reincidência e a contínua realimentação do sistema penal" (2013, online).

Em vista disso, constata-se que a "ressocialização" e a "humanização da pena” são temas há tempo preocupantes não somente ao sistema jurídico, mas a toda humanidade. Dessa preocupação constante, destaca-se, portanto, que o estudo "da evolução dos ideais, baseados no Iluminismo de Beccaria, busca explicar e fundamentar as tendências atuais da 'política criminal alternativa'. Em suma, o objetivo é passar da pena estritamente punitiva à ressocialização, no sentido de humanizar o Direito Penal" (Costa, 2015, online).

Não muito diferente do contexto social da França do início do Século $\mathrm{XIX}$, as questões sociais continuam exercendo forte influência "desde o cometimento do delito quanto ao retorno do sentenciado à liberdade, posto que, apesar de atualmente existir o regime progressivo de pena, livramento condicional, indultos e anistias, o fator social continua a marginalizar aqueles que, em tese, deveriam estar ressocializados" (Barbosa et al., 2016, online).

Certamente, o personagem Monsenhor Bienvenu instiga à reflexão do papel que cabe à sociedade perante sua quota de responsabilidade sobre o delito, as penas e, mais ainda, quanto à restauração e reinserção do egresso. Por meio desse personagem, portanto, chega-se à consciência de que em "todo fato criminoso há ao lado uma culpa de todos, uma culpa da 
sociedade, ideia de corresponsabilidade, e de que a pena deve ser necessariamente justa” (Programa Direito \& Literatura, 2012, online).

Monsenhor Bienvenu, portanto, oferece um caminho de análise de sua conduta versus a conduta ainda imperante numa sociedade que, ansiosa por punição, cega por segurança, descrente na humanidade, convicta de que "lugar de bandido é na prisão", felicita-se com penas cruéis, fazendo votos a reformas que resultem em aumento de pena e garantam, assim, a segurança e a paz social.

\section{CONSIDERAÇÕES FINAIS}

Embora se perpetuem aspectos de um ensino do Direito ainda influenciado por resquícios de um sistema jurídico educacional metódico, formalista e positivista, a tendência do ensino contemporâneo é a busca por estratégias inovadoras, interdisciplinaridade e métodos pedagógicos que auxiliem na formação de um jurista mais crítico, atento ao seu relevante papel social, com formação humanística sensível aos seus objetivos profissionais e humanos.

Contudo, o estabelecimento de uma ponte entre Direito e literatura, com enfoque nos estudos do "Direito na Literatura" - aquele que é analisado tendo como ponto de partida a obra literária e os aspectos jurídicos nela contidos - torna-se, portanto, de grande valia para um ensino interdisciplinar voltado à formação jurídica-crítica de um profissional sensível à complexidade da vida humana e seus conflitos sociais.

É por meio da arte literária e sua natureza atemporal, dada a sua função social educativa, formadora da sensibilidade crítica, relevante no papel da constituição do ser humano, que o estudo do direito pode ser transdisciplinar. Como visto, da análise interdisciplinar de grandes personagens da literatura universal resulta, evidentemente, um argumento de que é possível abordar aspectos jurídicos nas obras da literatura tendo como foco a formação humanística e sensível sobre a realidade refletida na ficção e as ligações com os fatos reais aos quais se relaciona o direito.

Jean Valjean, personagem central de Os miseráveis de Victor Hugo, é um herói romântico, idealizado, e como tal, não se insurge sobre a lei nem sobre sua pena, aceita-as resiliente. Vítima de um sistema penal rigoroso e cruel, cumpre integralmente sua sentença sem nenhuma perspectiva de 
ressocialização. Esse personagem representa os injustiçados do sistema penal e os estigmatizados pelo cárcere e pela discriminação social. Seu principal malfeitor, inspetor Javert, representante e estereótipo fiel do positivismo jurídico, tem como principal ânsia profissional capturar o fugitivo Jean Valjean e, assim, fazer-se cumprirem rigorosamente todas as leis.

Já o personagem do Bispo de Digne, Monsenhor Bienvenu, ao agir conforme valores e preceitos naturais e universais, quando oferece ao exforçado das galés uma oportunidade de justiça e liberdade, representa uma espécie de contrapeso da tirania, o extremo oposto de Javert, uma esperança em meio ao caos da vida de Jean Valjean. Enquanto um é a lei, o outro é a redenção, a possibilidade de reinserção social, a justiça que restaura a humanidade. Cada personagem, portanto, é uma possibilidade de reflexão em interface com um modelo de concepção jurídica.

Assim, cabe ressaltar que tais estudos interdisciplinares colaboram na conscientização do acadêmico, principalmente, quanto ao papel social que cumpre à universidade, ampliando a construção do conhecimento para além da dogmática e do tecnicismo, formando juristas conscientes do seu papel de entendimento e interferência no contexto social.

Esta pesquisa, como se observa, não se completa nem se esgota. Abre portas para outras e talvez novas descobertas proporcionadas pela experiência transdisciplinar em prol de uma mudança não somente relevante para o ensino jurídico, mas, essencialmente, ao modo como, enquanto juristas e não apenas operadores do direito, olhamos para o mundo.

\section{REFERÊNCIAS}

ARNEITZ, Juliana Azevedo. O direito sob o véu da literatura: entre homens e aranhas. Disponível em: <http://www.publicadireito.com.br/conpedi/manaus/arquivos/anais/forta leza/3666.pdf > Acesso em: 27 mar. 2017.

ARISTÓTELES. Poética. In: ARISTÓTELES; HORÁCIO; LONGINO. A poética clássica. Trad. de Jaime Bruna. São Paulo: Cultrix, 1981. p. 28.

BARBOSA, Jorge Luis Lemanski et al. Anais do VII CONCCEPAR Congresso Científico da Região Centro-Ocidental do Paraná; Faculdade Integrado de Campo Mourão, Paraná, 2016. Disponível em: $<$ http://conccepar.grupointegrado.br/resumo/uma-leitura-filosoficojuridicade-os-miseraveis-de-victor-hugo/480/787> . Acesso em: 26 abr. 2017. 
BITTAR, Eduardo Carlos Bianca; ALMEIDA, Guilherme Assis de. Curso de filosofia do direito. 10. ed. São Paulo: Atlas, 2012.

BOBBIO, Norberto. $O$ positivismo jurídico: lições de filosofia do direito. Compilação de Nello Morra. Trad. e notas de Márcio Pugliesi, Edson Bini e Carlos E. Rodrigues. São Paulo: Ícone, 1995.

CANDIDO, Antonio. Literatura e sociedade. 8. ed. São Paulo: T. A. Queiroz, 2000.

CARNEIRO, Cesar. Direito na obra Os miseráveis de Victor Hugo: um diálogo sob a ótica da Escola do Direito crítico. Disponível em: $<$ https://jus.com.br/artigos/45682/direito-na-obra-os-miseraveis-devictor-hugo-um-dialogo-sob-a-otica-da-escola-do-direito-critico $>$. Acesso em: 16 set. 2016.

COMPAGNON, Antoine. O demônio da teoria. Trad. de Cleonice P. B. Mourão e Consuelo F. Santiago. 2. ed. Belo Horizonte: UFMG, 2010.

COUTINHO, Afrânio. Notas de teoria literária. 2. ed. Rio de Janeiro: Civilização Brasileira, 1978.

COSTA, Gabriela Galdino da. Resenha do filme "Os miseráveis". Revista Transgressões: Ciências criminais em debate, v. 3, n. 1, p. 371-379, maio 2015. Disponível em: $<$ https://periodicos.ufrn.br/transgressoes/article/viewFile/6905/5348> Acesso em: 21 abr.2017.

CZEKSTER, Gustavo. Afinal, qual é a função da Literatura? Disponível em: $\quad<$ http://www.substantivoplural.com.br/afinal-qual-e-funcao-daliteratura/>. Acesso em: 26 mar. 2017.

SÖHNGEN, Clarice Beatriz da Costa; PANDOLFO, Alexandre Costi. Encontros entre direito e literatura: pensar a arte. Porto Alegre: EDIPUCRS, 2008.

SÖHNGEN, Clarice Beatriz da Costa; ÁVILA, Fabrício Dreyer de. Encontros entre direito e literatura III: poesia, linguagem e música. Porto Alegre: EDIPUCRS, 2015.

HUGO, Victor. Os miseráveis. Trad. de Regina Célia de Oliveira. São Paulo: Martin Claret, 2014.

LYRA FILHO, Roberto. O que é direito. São Paulo: Brasiliense, 1999.

NEVES, José Roberto de Castro. A invenção do direito: as lições de Ésquilo, Sófocles, Eurípedes e Aristófanes. 1. ed. Rio de Janeiro: Edições de Janeiro, 2015.

PROGRAMA DIREITO E LITERATURA. Os miseráveis. Rede Brasileira de Direito e Literatura. Disponível em: <https://vimeo.com/23007508>. Acesso em: 21 abr. 2017.

ROCCO, Maria Thereza Fraga. Leitura/Ensino: uma problemática. 2. ed. São Paulo: Ática, 1992.

SEMER, Marcelo. ...Os miseráveis do direito penal... Sem juízo (Blog), 17/o3/2013. Disponível em: <http://blogsemjuizo.com.br/os-miseraveisdo-direito-pena/>. Acesso em: 13 jun. 2016. 
SILVA, Silvano Gomes da. Direito e literatura: aporte metodológico e literário como recurso para a compreensão e ampliação do direito. Belo Horizonte: Mandamentos, 2010.

SIQUEIRA, Ada Bogliolo Piancastelli de. Notas sobre direito e literatura: o absurdo do direito em Albert Camus. Florianópolis: Fundação Boiteux, 2011.

STRECK, Lenio Luiz; TRINDADE, André Karam. Direito e literatura: da realidade da ficção à ficção da realidade. São Paulo: Editora Atlas, 2013.

TALAVERA, Pedro. Uma aproximação literária da relação entre Justiça e Direito. Anamorphosis - Revista Internacional de Direito e Literatura, v. 1, n. 2, p. 207-246, jul.-dez. 2015. Disponível em: $<$ http://rdl.org.br/seer/index.php/anamps/article/view/71>. Acesso em: 22 set. 2016. doi: 10.21119/anamps.12.207-246

TRINDADE, André Karam; GUBERT, Roberta Magalhães; COPETTI NETO, Alfredo (Org.). Direito e Literatura: reflexões teóricas. Porto Alegre: Livraria do Advogado, 2008.

TRINDADE, André Karam; GUBERT, Roberta Magalhães; COPETTI NETO, Alfredo (Org.). Direito \& Literatura: discurso, imaginário e normatividade. Porto Alegre: Núria Fabris Ed., 2010.

FOLHA UOL. Juíza manda prender desempregada, mãe de 10 filhos, por calote de fiança. Folha de São Paulo, Cotidiano, 09/08/2010. Disponível em: <http://www1.folha.uol.com.br/fsp/cotidian/ff0908201006.htm $>$ Acesso em: 14 abr. 2017.

VARGAS LLOSA, Mario. A tentação do impossível: Victor Hugo e Os miseráveis. Trad. de Paulina Wacht e Ari Roitman. Rio de Janeiro: Objetiva, 2012.

Idioma original: Português

Recebido: 30/11/17

Aceito: 04/04/18 